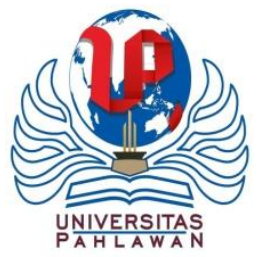

Jurnal Basicedu Volume 1 Nomor 1 Tahun 2017 Halaman 10-20

JURNAL BASICEDU

Research \& Learning in Elementary Education

http:// stkiptam.ac.id/indeks.php/basicedu

\title{
PENERAPAN METODE EKSPERIMENUNTUK MENINGKATKAN HASIL BELAJAR IPA SISWA KELAS IV SDN O11 LANGGINI KABUPATEN KAMPAR
}

\author{
Yenni Fitra Surya ${ }^{1}$ \\ ${ }^{1}$ Dosen Prodi PGSD Universitas Pahlawan Tuanku Tambusai \\ e-mail : Yenni.fitra13@gmail.com
}

\begin{abstract}
Abstrak
Penelitian ini berawal dari kenyataan di Sekolah Dasar bahwa pembelajaran sering didominasi oleh guru sebagai sumber informasi. Berdasarkan pengamatan peneliti ditemukan hasil belajar IPA siswa masih rendah, untuk itu peneliti melalui penelitian tindakan kelas ini ingin mencoba meningkatkan hasil pembelajaranIPA melalui metode eksperimen pada siswa kelas IV SDN 011 Langgini dengan jumlah siswa kelas IV SDN011 Langgini adalah 30 Orang, jumlah siswa laki-laki 16 orang dan siswa perempuan 14 orang. Jenis penelitian ini menggunakan penelitian tindakan kelas yang terdiri dari II siklus, dan setiap siklus ada 3 tahap yaitu langkah persiapan eksperimen, langkah pelaksanaan eksperimen, dan langkah tindak lanjut eksperimen dalam pembelajaran IPA. Subjek penelitian adalah siswa kelas kelas IV SDN 011 Langgini.Penilaian yang digunakan dalam pengumpulan data adalah penilaian proses menggunakan lembar observasi aktivitas guru dan lembar observasi aktivitas siswa dan penilaian hasil belajar. Data yang diperoleh dalam penelitian ini dianalisis dengan menggunakan tes dan menguji ketuntasan belajar dengan persentase.Dari nilai rata-rata hasil belajar IPA dengan menggunakan metode eksperimen pada siklus I dan siklus II mengalami peningkatan. Nilai siklus I dengan rata-rata 6,5 dan pada siklus II rata-rata 7,7.Dengan demikian dapat disimpulkan bahwa pembelajaran IPA dengan menggunakan metode eksperimen dapat meningkatkan hasil belajar siswa kelas IV SDN 011 Langgini Kabupaten Kampar.
\end{abstract}

Kata Kunci : Hasil Belajar,Metode Eksperimen, IPA 


\section{PENDAHULUAN \\ Latarbelakang}

Pada pembelajaran IPA (Ilmu

Pengetahuan Alam) dituntut siswa yangaktif dalam belajar. Sebab pembelajaran IPA merupakan serangkaian kegiatan proses ilmiah antara lain penyelidikan (eksperimen), penyusunan dan pengkajian gagasan serta konsep. Hal ini sejalan dengan pengertian IPA menurut Depdiknas (dalam Kurikulum Tingkat Satuan Pendidikan IPA 2006:484) adalah:

Ilmu pengetahuan alam berhubungan dengan cara mencari tahu tentang alam.Secara sistematis, sehingga Ilmu Pengetahuan Alam bukan hanya penguasaan kumpulan pegetahuan yang berupa teori-teori, faktafakta, konsep-konsep, atau prinsip-prinsip saja tetapi juga merupakansuatu proses penemuan. Pendidikan IPA diharapkan dapat menjadi wahana bagi peserta didik untuk mempelajari diri sendiri dan alam sekitar serta prospek pengembangan lebih lanjut di dalam menerapkannya dalam kehidupan sehari-hari.

Memang benar bahwa IPA merupakan suatu ilmu teoritis.Tetapi teori tersebut didasarkan atas pengamatan, percobaanpercobaan dan eksperimen. Jadi dapat dimaknai bahwa IPA adalah suatu pengetahuan teoritis yang diperoleh dengan cara yang khas atau khusus yaitu melakukan eksperimen dan penyimpulan.Dalam melakukan eksperimen diharapkan siswa mampu mengembangkan kemampuan dalam menggunakan metode tersebut dengan tepat dalam kegiatan pembelajaran dengan demikian guru berupaya menjadikan pembelajaran IPA yang menyenangkan bagi siswa. Guru tidak hanya menggunakan metode yang diinginkan saja, guru selalu menggunakan metode ceramah, dimana metode ini menurut peneliti kurang cocok untuk pembelajaran IPA, sesuai menurut pendapat Roestiyah (2001:76) salah satu metode yang cocok untuk pembelajaran IPA adalah metode eksperimen, Guru sering menggunakan metode yang kurang bervariasi sehingga penggunaan metode dalam pembelajaran IPA yang dilaksanakan tidak sesuai dengan tuntutan kurikulum. Padahal dalam Kurikulum Tingkat Satuan Pendidikan (KTSP) mata pelajaran IPA menekankan pada pemberian pengalaman belajar secara langsung melalui penggunaan dan pengembangan sikap ilmiah. Untuk mendapatkan pengalaman secara langsung proses pembelajaran dapat dilakukan dengan menggunakan metode eksperimen. Akibat dari pemakaian metode yang kurang tepat siswa menangkap pelajaran apa yang dikatakan guru.

Hasil belajar siswa tidak sesuai dengan harapan, siswa menjadi pasif sedangkan yang dominan dalam kelas hanyalah guru.Hal ini sejalan menurut Stevani (dalam http://.google.co.id/search=penguasaan iptek,) masalah pembelajaran sains/IPA khususnya ditingkat Sekolah Dasar (SD) pembelajaran IPA di sekolah bersifat informatif di bawah koordinasi guru.Selain itu masih banyak guru yang mengajarkan IPA kurang menguasai materi dan konsep pembelajaran.

Dalam pembelajaran IPA salah satu metode yang cocok menurut Muhibbin (2007:209) yaitu metode eksperimen.Tapi tidak semua materi pembelajaran dalam IPA yang cocok dengan menggunakan metode eksperimen. Dengan melakukan percobaan berarti siswa mengamati sendiri kegiatan yang dilakukan dan melakukan sendiri kegiatan, sehingga siswa akan lebih aktif serta memperolah pengalaman langsung.

Berdasarkan hasil observasi yang penulis laksanakan dengan guru di kelas IV SDN 011 Langgini bahwa guru tersebut mengajar dengan menerangkan di depan kelas artinya guru menggunakan metode ceramah saja dalam mengajarkan IPA. Sehingga siswa kurang bersemangat dalam belajar.Hasil belajar yang didapat dari pembelajaran yang dilakukan seperti ini tidak sesuai dengan harapan. Dengan tanya jawab antara penulis dengan siswa, siswa sering merasa bosan belajar karena metode yang diajarkan kurang bervariasi. Akibatnya siswa tidak serius dalam belajar, sehingga hasil belajar tidak sesuai dengan harapan.Nilai siswa lebih banyak yang rendah dibandingkan dengan yang tinggi.hasil 
belajar rendah dapat terbukti dari hasil ujian semester I siswa kelas IV yaitu dari tiga puluh dua siswa hanya sepuluh siswa yang mendapatkan nilai lebih dari lima puluh keatas.

Berdasarkan latar belakang masalah diatas, maka penulis tertarik untuk melakukan penelitian dengan judul "Penerapan Metode Demontrasi Untuk Meningkatkan Hasil Belajar IPA di Kelas IV Sekolah Dasar Negeri 011 Langgini.

\section{Rumusan Masalah}

Berdasarkan uraian di atas maka dapat dirumuskan masalah sebagai berikut: Apakah PenerapanMetode

DemosntrasiDapatMeningkatkanHasil

BelajarIPA Siswa di Kelas IV Sekolah Dasar Negeri 016 Langgini?

\section{Tujuan Penelitian}

Penelitian yang dilaksanakan bertujuan untuk meningkatkan Hasil Belajar IPASiswa di kelas IV Sekolah Dasar Negeri 011 Langgini dengan penerapan Metode Eksperimen.

\section{KAJIAN TEORI}

\section{Metode Eksperimen}

Udin (1993:219) menyatakan Metode eksperimen adalah Suatu cara penyajian materi pelajaran dimana siswa secara sendiri aktif mengalami dan membuktikan tentang apa yang sedang dipelajarinya. Melalui metode ini siswa secara total dilibatkan dalam: melakukan sendiri, mengikuti suatu proses, mengamati suatu objek, menganalisis, membuktikan dan menarik kesimpulan sendiri tentang suatu objek, keadaan atau proses sesuatu. Menurut R. Ibrahim (2007:107) "Metode eksperimen adalah langsung melibatkan para siswa melakukan percobaan untuk mencari jawaban terhadap permasalahan yang diajukan.

Berdasarakan beberapa pendapat beberapa para ahli di atas dapat dimaknai pengertian metode eksperimen memberikan kesempatan seluas-luasnya kepada siswa untuk melakukan berbagai kegiatan pembelajaran. Siswa dapat melakukan, mengambil dan mencatat hasil percobaan
tersebut.Jadi melalui metode eksperimen ini siswa diharapkan dapat menemukan sendiri jawaban permasalahan yang sedang dihadapinya.Pembelajaran dengan metode eksperimen melatih dan mengajar siswa untuk belajar konsep IPA.Siswa belajar secara aktif dengan mengikuti tahap-tahap pembelajarannya. Dengan demikian, siswa akan menemukan sendiri konsep sesuai dengan hasil yang diperoleh selama pembelajaran. Dalam metode eksperimen, guru dapat mengembangkan keterlibatan fisik dan mental, serta emosional siswa. Siswa mendapat kesempatan untuk melatih keterampilan proses agar memperoleh hasil belajar yang maksimal. Pengalaman yang dialami secara langsung dapat tertanam dalam ingatannya. Keterlibatan fisik dan mental serta emosional siswa diharapkan dapat diperkenalkan pada suatu cara atau kondisi pembelajaran yang dapat menumbuhkan rasa percaya diri dan juga perilaku yang inovatif dan kreatif.

Menurut pendapat (Udin 1993:220221) langkah-langkah melakukan eksprimen ada 3 sebagai berikut:

a.Langkah persiapan

Persiapan ini penting artinya untuk sebuah eksperimen. Sebab dengan persiapan yang matang kelemahankelemahan atau kegagalan yang akan muncul dapat diperkecil. Persiapan untuk pelaksanaan metode eksperimen antara lain:

1.Menetapkan tujuan eksperimen.

2.Mempersiapkan alat atau bahan yang diperlukan.

3.Mempersiapkan tempat eksperimen.

4.Mempertimbangkan jumlah siswa dengan jumlah alat yang ada dan kapasitas tempat eksperimen.

5.Mempersiapkan tata tertib terutama untuk menjaga peralatan dan bahan yang digunakan.

6.Memperhatikan resiko keamanan.

7.Membuat petunjuk tentang langkahlangkah yang harus ditempuh selama eksperimen berlangsung secara 
sistematis, termasuk hal-hal yang dilarang atau yang membahayakan.

b. Langkah pelaksanaan metode eksperimen

1.Sebelum siswa melaksanakan eksperimem, siswa mendiskusikan persiapan dengan guru. Setelah itu barulah meminta alatalat atau perlengkapan yang akan digunakan dalam eksperimen.

2.Selama berlangsungnya proses pelaksanaan metode eksperimen guru perlu mendekati siswa untuk mengamati proses eksperimen yang sedang dilaksanakan. Menerima pertanyaanpertanyaan yang sedang dilaksanakan.Memberikan dorongan dan bantuan terhadap kesulitan-kesulitan yang dihadapi siswa sehingga eksperimeneksperimen tersebut dapat diselesaikan.

3.Selama eksperimen berjalan, guru hendaknya memperhatikan situasi secara keseluruhan seluruh eksperimen.

4.Siswa melakukan eksperimen dengan LKS yang diberikan.

c. Tindak lanjut metode eksperimen. Setelah eksperimen dilakukan, kegiatan selanjutnya antara lain adalah:

1.Meminta siswa untuk membuat laporaan untuk diperiksa.

2.Mendiskusikan masalah-masalah yang ditemukan dalam eksperimen.

3. Memeriksa keberhasilan alat atau menyimpan kembali segala peralatan yang digunakan.

\section{Hasil Belajar}

Hasil belajar merupakan Berhasil atau tidaknya guru dalam membelajarkan siswa tergantung dari proses yang dialami siswa dalam balajar. Hasil balajar dapat berupa keterampilan, nilai dan sikap setelah siswa tersebut mengalami proses balajar. Apabila sudah terjadi perubahan tingkah laku seseorang, maka seseorang sudah dikatakan berhasil dalam belajar.Sebagaimana hal yang dikemukakan oleh Oemar (2007:21) bahwa "hasil belajar adalah tingkah laku yang timbul, misalnya dari tidak tahu menjadi tahu, timbulnya pertanyaan baru, perubahan dalam tahap kebiasaan, keterampilan, kesanggupan menghargai, perkembangan sifat sosial, emosional dan perubahan jasmani".Hasil belajar merupakan tolak ukur yang digunakan untuk menentukan tingkat keberhasilan siswa dalam memahami konsep dalam belajar. Apabila sudah terjadi perubahan tingkah laku seseorang, maka seseorang sudah dikatakan berhasil dalam belajar, sebagaimana yang telah dikemukakan oleh Oemar (20017:22) hasil belajar adalah "tingkah laku yang timbul, misalnya dari yang tidak tahu menjadi tahu, timbulnya pertanyaan baru, perubahan dalam tahap kebiasaan keterampilan, kesanggupan menghargai, perkembangan sikap sosial, emosional dan pertumbuhan jasmani”.

Hasil belajar siswa juga dapat dilihat dari kemampuan siswa dalam mengingat pelajaran yang telah disampaikan guru selama proses pembelajaran dan bagaimana siswa tersebut bisa menerapkan dalam kehidupan sehari-harinya serta mampu untuk memecahkan masalah yang ada. Hal ini sesuai dengan pendapat Purwanto (1996:18) "hasil belajar siswa dapat ditinjau dari beberapa aspek kognitif yaitu kemampuan siswa dalam pengetahuann (ingatan), pemahaman, penerapan (aplikasi), analisis, sintesis dan evaluasi".

Jadi hasil belajar siswa dapat dilihat dari kemampuannya dalam mengingat pelajaran yang telah disampaikan selama pembelajaran yang dinyatakan dalam skor dari hasil tes dan bagaimana siswa tersebut bisa menerapkannya serta mampu memecahkan masalah yang timbul sesuai dengan apa yang telah dipelajarinya.Hasil belajar IPA yang dimaksud disini adalah hasil belajar kognitif yang diperoleh peserta didik sebelum dan sesudah mengalami proses pembelajaran IPA dengan menggunakan metode eksperimen dalam setiap aktivitas yang dilakukan oleh peserta didik.

\section{Pembelajaran IPA}

Connant James (dalam Usman 2006:1)mendefinisikan “ IPA sebagai suatu deretan konsep serta skema konseptual yang 
berhubungan satu sama lain, dan yang tumbuh sebagai hasil eksperimentasi dan observasi, serta berguna untuk diamati dan dieksperimentasikan lebih lanjut".Selanjutnya menurut Whitehead (dalam Usman2006;1) "IPA dibentuk karena pertemuan dua orde pengalaman. Orde pertama adalah orde observasi yang didasarkan pada hasil observasi terhadap observasi atau gejala, orde kedua adalah orde konseptual yang didasarkan pada konsep-konsep manusia mengenai alam".Athur A Carin dan Rober B Sund (2003:122) mendefinisikan IPA adalah "pengetahuan yang sistematis atau tersusun secara teratur berlaku umum dan berupa kumpulan data hasil observasi dan eksperimen".

Berdasarkan beebrapa pendapat di atas dapat diartikan bahwa IPA adalah merupakan ilmu yang teoritis diperoleh dengan metoda khusus yang mendapatkan suatu konsep, tetapi teori tersebut didasarkan atas percobaan, dan eksperimen. Dilihat dari pengertian IPA ini maka peneliti berkeinginan untuk melakukan penelitian dengan menggunakan metode eksperimen. Prinsip-prinsip pembelajaran IPA (dalam http://www.UNY.hakikatIPA.doc.

27 Maret 2017) sebagai berikut:

a. Prinsip motivasi: daya dorong seseorang untuk melakukan sesuatu kegiatan.

b. Prinsip latar: pada hakekatnya siswa telah memiliki pengetahuan awal.

c. Prinsip menemukan: pada dasarnya siswa memiliki rasa ingin tahu yang besar sehingga potensial untuk mencari guna menemukan sesuatu.

d. Prinsip belajar sambil melakukan sesuatu (learning by doing): pengalaman yang diperoleh melalui bekerja merupakan hasil belajar yang tidak mudah terlupakan.

e. Prinsip belajar sambil bermain: bermain merupakan kegiatan yang dapat menimbulkan suasana gembira dan menyenangkan, sehingga akan dapat mendorang siswa untuk melibatkan diri dalam proses pembelajaran.

f. Prinsip hubungan sosial: dalam beberapa hal kegiatan belajar akan lebih berhasil jika dikerjakan secara berkelompok.
Berdasarkan prinsip-prinsip di atas dapat peneliti simpulkan, bahwa guru hendaknya dapat menciptakan suasana pembelajaran yang membuat siswa senang sehingga siswa akan terlibat aktif dalam pembelajaran. Supaya keenam prinsip di atas dapat diterapkan, guru dalam mengelola pembelajaran perlu sebagai berikut: 1) Menyajikan kegiatan yang beragam sehingga siswa tidak jenuh, 2) Menggunakan sumber belajar yang bervariasi, di samping buku acuan, 3) Memanfaatkan lingkungan sekitar sebagai sumber belajar, karena belajar akan lebih bermakna apabila berhubungan langsung pada permasalahan lingkungan sekitar kita, 4) Kreatif menghadirkan alat Bantu pembelajaran, 5) Menciptakan suasana kelas yang menarik.Penjelasan di atas dapat disimpulkan bahwa pembelajaran IPA merupakan suatu proses pembelajaran yang terencana dan terprogram yang melibatkan guru dengan menyusun suatu rancangan Rencana Pelaksanaan Pembelajaran (RPP) dan melaksanakan pembelajaran sesuai dengan metode eksperimen.

\section{METODOLOGI PENELITIAN}

Jenis peneltian yang dilaksanakanyaitu Peneltian Tindakan Kelas (PTK) yang peneliti gunakan pendekatan kualitatif, karena peneliti ingin mengamati fenomena yang terjadi di lapangan. Jenis penelitian ini adalah Penelitian Tindakan Kelas (PTK) atau Action Research.Penelitian Tindakan Kelas adalah penelitian yang dilakukan oleh guru di dalam kelasnya sendiri melalui refleksi diri, dengan tujuan utama memperbaiki kinerjanya sebagai guru.Sehingga hasil belajar siswa menjadi meningkat (Wardani 2002:14). PTK adalah proses yang dilakukan oleh perorangan atau kelompok yang menghendaki perubahan dalam situasi tertentu (dalam Rita Wati 2007:15).Dari pengertian di atas dapat disimpulkan bahwa dengan adanya penelitian tindakan kelas ini, harus datang dari keinginan guru itu sendiri untuk melakukan perubahan terhadap proses pembelajaran yang dilakukan guru di dalam kelas. 
Esensi dari penelitian tindakan kelas terletak pada adanya tindakan dalam situasi yang alami untuk memecahkan permasalahan praktis atau untuk memecahkan masalah pembelajaran IPA di kelas IV SDN 011 Langgini.Berdasarkan pendapat Kemmis dan McTaggart (dalam Rita 2007:11):

Proses penelitian tindakan kelas merupakan proses daur ulang atau siklus yang dimulai dari aspek pengembangan, perencanaan, melakukan tindakan sesuai rencana, melakukan observasi terhadap tindakan, dan melakukan refleksi yaitu perenungan terhadap perencanaan, kegiatan tindakan, dan kesuksesan hasil yang diperoleh. Sesuai dengan prinsip umum penelitian tindakan setiap tahapan dan siklusnya selalu secara partisipatoris dan kolaboratif antara peneliti dan praktisi guru dan kepala sekolah dalam sistem persekolahan.

Kegiatan penelitian dilaksanakan berdasarkan perencanaan tindakan yang telah ditetapkan, yaitu pembelajaran dilaksanakan sesuai dengan Rencana Pelaksanaan Pembelajaran (RPP) yang telah dibuat.Fokus tindakan pada penelitian ini adalah penggunaan metode demonstrasi yang dioptimalkan untuk meningkatkan pembelajaran IPA.Pada tahap pelaksanaan tindakan ini, proses pembelajaran dilaksanakan dengan menjalankan skenario pembelajaran yang telah dirancang dan terdapat dalam RPP.

\section{HASIL DAN PEMBAHASAN}

\section{Siklus I}

\section{a. Perencanaan Tindakan}

Pada tahap perencanaan materi pembelajaran yang dilaksanakan pada siklus I adalah menyebutkan sumber-sumber energi panas dengan menggunakan metode eksperimen (percobaan). Pada awal pembelajaran difokuskan pada memotivasi dan merangsang siswa dengan melakukan tanya jawab tentang sumber-sumber energi panas yang diketahui siswa dalam kehidupan sehari-hari. Pembelajaran dilaksanakan dengan metode tanya jawab. Indikator pembelajaran ini adalah (1) menyebutkan sumber-sumber energi panas, misalnya panas matahari untuk mengeringkan pakaian. (2) melakukan percobaan adanya perpindahan panas. Penilaian/ Evaluasi yang diberikan adalah (1) evaluasi proses aspek yang dinilai kerja sama dengan kelompok, aktifitas dalam percobaan, ketepatan jawaban dalam percobaan, ketelitian menggunakan alat. (2) evaluasi hasil diberikan berupa soal objektif.

Pelaksanaan pembelajaran ini memerlukan alat dan bahan untuk melakukan percobaan. Alat yang digunakan adalah elemeyer, kawat kasa, kaki segi tiga/ kompor. Sedangkan bahan yang digunakan adalah lilin, korek api, mentega, tembaga, aluminium, besi, kayu, air, spritus, serbuk gergaji dan balok kecil. Pelaksanaan tindakan dimulai dengan penyampaian materi (1) membagi siswa menjadi empat kelompok, (2) menjelaskan cara-cara melakukan eksperimen, (3) dengan kelompok yang telah ditentukan guru, siswa melakukan percobaan, (4) mengawasi dan membimbing dalam melakukan percobaan, (5) melaporkan hasil percobaan sesuai LKS dan kelompok lain menanggapi hasil laporan, (6) diskusi tentang hasil percobaan antar kelompok, (7) melakukan tanya jawab tentang hasil laporan, (8) menyimpulkan pelajaran.

\section{b. Pelaksanaan Tindakan}

Pelaksanaan pembelajaran siklus 1 ini sesuai dengan rencana yang telah ditetapkan. Dalam pelaksanaan tindakan peneliti bertindak sebagai guru. Mengawali tindakan pembelajaran ini peneliti mengucapkan salam kemudian menyampaikan topik yang akan dipelajari yaitu energi panas dengan menggunakan metode eksperimen. Setelah itu peneliti menyampaikan tujuan yang ingin dicapai.Sebelum memulai pembelajaran inti, peneliti terlebih dahulu memberi kesempatan bertanya kepada siswa mengenai percobaan yang akan dilakukan sesuai dengan LKS yang sudah ada, supaya dalam melakukan percobaan siswa tidak mengalami kesulitan. Namun siswa tidak ada yang bertanya, dan akhirnya peneliti menjelaskan cara-cara melakukan percobaan.

Pada kegiatan inti guru membagi siswa menjadi 4 kelompok dan siswa pun duduk 
pada kelompoknya masing-masing, pembagian kelompok dibagi berdasarkan kemampuan siswa.Kemudian guru menjelaskan cara-cara melakukan eksperimen.Kemudian guru membagikan LKS dan menugasi siswa untuk melakukan percobaan dan mengisi LKS.Mendiskusikan secara bersama di bawah bimbingan guru.Mengakhiri pembelajaran dengan membuat kesimpulan secara bersama-sama dan mengerjakan evaluasi.

Masalah yang dibahas dalam pertemuan ini adalah energi panas dapat berpindah secara secara konduksi dan konveksi dengan menggunakan alat-alat dan bahan misalnya: elemenyer, kompor kecil, kawat kasa, spritus dll. Siswa melakukan percobaan dalam kelompok serta mendiskusikan hasil percobaan dan menuliskannya dalam laporan.Setelah selesai diskusi kelompok dilanjutkan dengan diskusi kelas untuk menyampai hasil diskusi kelompok.Selanjutnya siswa di bawah bimbingan guru membuat kesimpulan bersama dan membuat catatan hasil percobaan dibuku catatan masing-masing. Di samping itu guru melakukan penilaian proses saat siswa melakukan percobaan dan diskusi. Akhir kegiatan guru memberikan tes tertulis untuk penguasaan kognitif siswa.Penilaian/ evaluasi hasil dapat dilihat pada lampiran 18 .

Hasil latihan yang diperoleh pada siklus I baru mencapai $67 \%$ sedangkan ketuntasan yang diharapkan adalah $70 \%$.Sebagian siswa masih mengalami kesulitan dalam menjawab soal mengenai energi panas. Dari 30 orang siswa kelas IV didapatkan rincian penghitungan nilai masingmasing siswa dengan penilaian sebagai berikut: 5 oarang siswa mendapat nilai 80,8 oarang siswa mendapat nilai 70,14 oarang siswa mendapat nilai 60 , dan 3 oarang siswa mendapat nilai 50. Pada kegiatan penutup siswa dengan bimbingan guru menyimpulkan kegiatanpembelajaran secara bersama-sama.

\section{c. Observasi}

Berdasarkan hasil observasi yang dilakukan pada siklus I,Data hasil observasi dari aspek guru dan siswa selama mengikuti proses pembelajaran sebagai berikut:Pada kegiatan awal guru menyampaikan tujuan pembelajaran yang akan dipelajari siswa tetapi guru tidak menyampaikan tujuan pembelajaran sehinga siswa tidak mengetahui apa yang akan dipelajari. Kegiatan selanjutnya melakukan tanya jawab tentang energi panas yang diketahui siswa dalam kehidupan seharihari akan tetapi pertanyaan yang diberikan guru kepada siswa untuk memotivasi siswa untuk merangsang minat siswa melakukan eksperimen yang akan dilakukan, disini guru hanya sedikit sekali memberikan pertanyaan yang seharusnya masih pertanyaan yang bisa diberikan sesuai dengan eksperimen yang akan dilakukan. Setelah itu guru menjelaskan langkah-langkah pembelajaran tentang percobaan yang akan dilakukan siswa. Guru mengadakan tanya jawab tentang alat dan bahan yang digunakan dalam percobaan. Siswa bersemangat dan antusias sekali melihat alat-alat itu.

Pada kegiatan inti guru melakukan pembagian kelompok, jumlah siswa masingmasing kelompok sebanyak 7-8 orang. Setelah itu dilanjutkan dengan membagikan LKS pada masing-masing kelompok dan guru menjelaskan langkah-langkah kerja dalam LKS. Guru menyuruh siswa melakukan percobaan, dengan serius dan hati-hati. Selesai melakukan percobaan siswa mengisi LKS serta mendiskusikan dengan anggota kelompok.Selanjutnya di bawah bimbingan guru diadakan diskusi kelas untuk menyampaikan hasil diskusi masing-masing kelompok. Dalam melaporkan siswa tidak mau ke depan kelas dan akhirnya dilaporkan sambil duduk saja. Dalam melaporkan hasil diskusi tidak berjalan sesuai dengan rencana karena siswa atau kelompok lain tidak ada yang menanggapi, hal ini terjadi karena siswa sudah terbiasa menerima dari guru dan tidak terbiasa berdiskusi. Ada satu orang siswa yang bertanya tapi kelompok yang melaporkan tidak bisa menjawab yang akhirnya guru yang menjawab.Diakhir diskusi kelas siswa di 
bawah bimbingan guru membuat kesimpulan dari percobaan yang telah dilakukan dan siswa mencatatnya dalam buku catatan masingmasing.Setelah semua kegiatan belajar mengajar selesai ringkasan hanya dibagikan saja kepada siswa.Begitu juga dengan penilaian/ evaluasi hasil di jadikan pekerjaan rumah.

Penggunaan metode eksperimen ini membuat pelajaran IPA menjadi lebih menyenangkan. Guru kurang bisa merencanakan waktu dengan baik karena materi yang akan diajarkan sangat banyak hal ini menyebabkan waktu untuk berdiskusi dan penilaian kurang. Dari segi siswa pengamat melaporkan sebagai berikut: siswa menanggapi pertanyaan yang diberikan oleh guru dengan baik. Siswa sangat antusias untuk melakukan percobaan yang belum pernah dilakukannya.Siswa bekerja dalam kelompok dengan sangat baik tetap tidak semua siswa yang serius dalam melakukan percobaan, masih didominasi oleh siswa yang pintar dalam mengisi LKS hal ini terbukti saat guru bertanya pada salah seorang siswa bahwa dia tidak ikut mengisi LKS.Pada saat siswa disuruh dalam melaporkan hasil diskusi tidak mau ke depan kels karena malu dan akhirnya dibacakan di tempat duduk saja. Siswa belum terbiasa berdiskusi dalam belajar sehingga diskusi tidak terlaksana dengan baik.

\section{d. Refleksi}

Kegiatan refleksi dilakukan secara kolaboratif antara guru kelas dan praktisi sebagai observer pada setiap pembelajaran berakhir Pembelajaran siklus I difokuskan pada melakukan percobaan atau eksperimen. Pembelajaran dilaksanakan dengan menerapkan belajar kelompok.Untuk memperoleh data yang tentang pelaksanaan siklus I dilakukan lembar catatan lapangan dan rambu-rambu analisis. Hasil pengamatan catatan lapangan dan rambu-rambu analisis selama pelaksanaan tindakan dianalisis dan didiskusikan dengan pengamat sehingga diperoleh hal-hal sebagai berikut:

Pada kegiatan pembelajaran awal diperoleh hal-hal antara lain: (1) guru hendaknya menyampaikan tujuan pembelajaran yang ingin dicapai, agar siswa mengetahui apa yang dipelajari saat itu. (2) dalam melakukan tanya jawab, guru hendaknya tidak bertanya secara klasikal, karena secara klasikal tidak bisa diukur secara individu. Kalau disuruh menjawab secara individu siswa kurang berani karena sudah terbiasa menjawab bersama-sama.

Pada kegiatan inti pembelajaran diperoleh hal-hal antara lain: (1) dalam proses percobaan, guru cuma mengawasi dan membimbing namun guru masih belum sepenuhnya percaya pada siswa untuk memberikan tanggung jawab yang penuh, karena guru masih menganggap siswa belum mampu. (2) Belum semua siswa yang aktif dalam melakukan percobaan, hal inio disebabkan karena siswa belum terbiasa melakukan percobaan. (3) Saat melaporkan hasil diskusi, siswa malu ke depan dan akhirnya dibacakan sambil duduk, siswa kurang tahu cara berdiskusi, interaksi antara anggota kelompok kurang berjalan secara aktif. Oleh sebab itu, guru perlu menjelaskan cara berdiskusi yang baik, bagaimana cara menanggapi, menunggu giliran bicara dan menjelaskan bagaimana cara menjawab dengan baik.

Pada akhir pembelajaran diperoleh halhal antara lain: (1) membuat ringkasan dan kesimpulan perlu ditingkatkan. (2) Karena kekurangan waktu siswa diberi evaluasi dan dikerjakan di rumah. (3) hasil belajar siklus I, dari empat kelompok baru kelompok tiga yang mendapatkan rata-rata ketuntasan hasil belajar, kelompok yang lain masih di bawah rata-rata ketuntasan. Kelompok yang masih di bawah rata-rata ketuntasan masih perlu diberikan bimbingan yang lebih.

Dari 30 orang siswa yang mengikuti penilaian yang diadakan diakhir siklus I terdapat 13 orang yang mendapatkan nilai 70 keatas sesuai dengan standar keberhasilan yang ditetapkan yaitu 70 , sehinggan siswa tersebut dikatakan tuntas dalam belajar, sedangkan siswa yang mendapatkan di bawah nilai standar keberhasilan sebanyak 17 orang. Jadi persentase siswa yang tuntas belajar 
sebanyak $43 \%$. Hasil belajar dapat dilihat pada lampiran 21.

Berdasarkan hasil pengamatan observer dan kolaborasi setelah proses pembelajaran diperoleh hal-hal sebagai berikut: (1) adanya kesadaran guru dan peneliti tentang kekurangan-kekurangan yang dirasakan pada saat pembelajaran berlangsung. (2) adanya keinginan atau inisiatif guru untuk memperbaiki kekurangannya. (3) metode yang dipakai sudah cocok dengan materi ajar. (4) adanya semangat dan motivasi siswa untuk belajar. (5) adanya kerja sama antara siswa dalam pembelajaran. (6) Bisa menemukan konsep sendiri melalui bimbingan guru.

Kendala yang dihadapi selama pembelajaran antara lain: (1) peneliti masih kaku dalam pembelajaran karena diamati oleh pengamat. (2) penggunaan waktu belum sesuai dengan perencanaan (RPP). (3) masih ada siswa yang belum aktif. (4) percobaan yang dilakukan tidak sesuai waktu yang tersedia.

Pencapaian rambu-rambu analisis karakteristik penerapan metode eksperimen dari aspek guru hanya 65\%. (1) pencapaian rambu-rambu analisis karakteristik penerapan metode eksperimen dari aspek siswa hanya 62,5\%. (2) rambu-rambu keberhasilan mengajar guru hanya $67 \%$, dapat dilihat pada lampiran 9 dan 10. (3) nilai rata-rata kelas, ketuntasan hasil belajar masih rendah, ketuntasan hasil belajar dapat dilihat pada lampiran 23. Peneliti akan menerapkan kembali pelaksanaan siklus II dengan cara yang lebih baik untuk mendapatkan hasil yang memuaskan dalam menggunakan metode eksperimen.

\section{Siklus II}

\section{a. Perencanaan Tindakan}

Hasil analisis refleksi pada siklus I pada pertemuan pertama dan kedua menunjukkan perlunya dilanjutkan ke siklus yang ke II. Pembelajaran siklus II diberikan agar siswa dapat melakukan eksperimen atau percobaan sesuai dengan langkah-langkah yang dijelaskan. Pembelajaran siklus II dilaksanakan dalam satu kali pertemuan dengan alakasi waktu 3 x 35 menit.Indikator pembelajaran adalah (1) menyebutkan sumber-sumber energi bunyi, misalnya mendengar bunyi lonceng, suara guru. (2) melakukan percobaan sumber-sumber energi bunyi. Rencana pembelajaran selain memuat indikator juga memuat materi pembelajaran, materi pokok, metode.Selangkapnya rencana pembelajaran siklus II dapat dilihat pada lampiran 2.Agar peneliti dapat melaksanakan tugasnya dengan baik pengamat mengamati lembar obsevasi yang telah disediakan peneliti. Selesai peneliti melakukan proses belajar mengajar baru diadakan diskusi dengan pengamat.

\section{b. Pelaksanaan Tindakan}

Peneliti memulai pembelajaran dengan mengucapkan salam kemudian mengecek kehadiran siswa. Pelaksanaan pembelajaran siklus II ini sesuai dengan rencana pembelajaran yang telah ditetapkan. Mengawali tindakan pembelajaran guru mengucapkan salam kemudian menyampaikan topik yang akan dipelajari yaitu energi bunyi dengan menggunakan metode eksperimen. Setelah itu peneliti menyampaikan tujuan yang ingin dicapai.Sebelum memulai pembelajaran inti, peneliti terlebih dahulu memberi kesempatan bertanya kepada siswa mengenai percobaan yang akan dilakukan sesuai dengan LKS yang sudah ada, supaya dalam melakukan percobaan siswa tidak mengalami kesulitan. Siswa banyak yang bertanya tentang percobaan yang aka Pada kegiatan inti guru membagi siswa menjadi 4 kelompok dan siswa pun duduk pada kelompoknya masing-masing, pembagian kelompok dibagi berdasarkan kemampuan siswa. Kemudian guru menjelaskan cara-cara melakukan eksperimen.Kemudian guru membagikan LKS dan menugasi siswa untuk melakukan percobaan dan mengisi LKS.Mendiskusikan secara bersama di bawah bimbingan guru.Mengakhiri pembelajaran dengan membuat kesimpulan secara bersamasama dan mengerjakan evaluasi.

Masalah yang dibahas dalam pertemuan ini adalah energi bunyi disebabkan oleh benda yang bergetar dengan menggunakan alat-alat dan bahan misalnya: 
rol. Siswa melakukan percobaan dalam kelompok serta mendiskusikan hasil percobaan dan menuliskannya dalam laporan.Setelah selesai diskusi kelompok dilanjutkan dengan diskusi kelas untuk menyampai hasil diskusi kelompok.Selanjutnya siswa dibawah bimbingan guru membuat kesimpulan bersama dan membuat catatan hasil percobaan dibuku catatan masing-masing. Di samping itu guru melakukan penilaian proses saat siswa melakukan percobaan dan diskusi. Akhir kegiatan guru memberikan tes tertulis untuk penguasaan kognitif siswa.

Hasil latihan yang diperoleh pada siklus II mencapai $77 \%$. Siswa sudah bisa menjawab soal dengan baik mengenai energi bunyi. Dari 30 orang siswa kelas IV didapatkan rincian penghitungan nilai masingmasing siswa dengan penilaian sebagai berikut: 6 oarang siswa mendapat nilai 90, 10 orang siswa mendapat nilai 80, 14 oarang siswa mendapat nilai 70 .

\section{c. Observasi}

Observasi yang dilaksanakan pada pembelajaran siklus II dianalisis melalui lembar observasi aktivitas guru dan lembar observasi aktivitas siswa.Data hasil observasi dari aspek guru dan siswa selama mengikuti proses pembelajaran sebagai berikut dari segi guru, pada kegiatan awal guru menyampaikan tujuan pembelajaran yang akan dipelajari agar siswa dapat mengetahui apa yang akan dipelajari. Kegiatan selanjutnya melakukan tanya jawab tentang energi bunyi yang diketahui siswa dalam kehidupan sehari-hari pertanyaan yang diberikan guru kepada siswa untuk memotivasi siswa untuk merangsang minat siswa melakukan eksperimen yang akan dilakukan, guru sudah memberikan pertanyaan yang bisa memotivasi siswa tentang eksperimen yang akan dilakukan. Setelah itu guru menjelaskan langkah-langkah pembelajaran tentang percobaan yang akan dilakukan siswa. Guru mengadakan tanya jawab tentang alat dan bahan yang digunakan dalam percobaan. Siswa bersemangat dan antusias sekali melihat alat-alat itu.
Pada kegiatan inti guru melakukan pembagian kelompok, jumlah siswa masingmasing kelompok sebanyak 7-8 orang. Setelah itu dilanjutkan dengan membagikan LKS pada masing-masing kelompok dan guru menjelaskan langkah-langkah kerja dalam LKS. Guru menyuruh siswa melakukan percobaan, dengan serius dan hati-hati. Selesai melakukan percobaan siswa mengisi LKS serta mendiskusikan dengan anggota kelompok.Selanjutnya di bawah bimbingan guru diadakan diskusi kelas untuk menyampaikan hasil diskusi masing-masing kelompok. Dalam melaporkan siswa sudah mau ke depan kelas untuk melaporkan hasil diskusi. Dalam melaporkan hasil diskusi sudah berjalan sesuai dengan rencana dan kelompok lain ada yang menanggapi Diakhir diskusi kelas siswa di bawah bimbingan guru membuat kesimpulan dari percobaan yang telah dilakukan dan siswa mencatatnya dalam buku catatan masing-masing. Penilaian/ evaluasi hasil sudah dikerjakan siswa di dalam kelas.

Penggunaan metode eksperimen ini membuat pelajaran IPA menjadi lebih menyenangkan. Guru bisa merencanakan waktu dengan baik dan waktu untuk berdiskusi dan penilaian cukup. Dari segi siswa, pengamat melaporkan sebagai berikut: siswa menanggapi pertanyaan yang diberikan oleh guru dengan baik. Siswa sangat antusias untuk melakukan percobaan yang belum pernah dilakukannya.Siswa bekerja dalam kelompok dengan sangat baik semua siswa serius dalam melakukan percobaan, tidak didominasi oleh siswa yang pintar dalam mengisi LKS.Pada saat siswa disuruh dalam melaporkan hasil diskusi sudah mau ke depan kelas untuk melaporkan. Siswa sudah bisa berdiskusi dalam belajar sehingga diskusi terlaksana dengan baik.

\section{d. Refleksi}

Kegiatan refleksi dilakukan secara Dari pengamatan peneliti dan observer pada pertemuan II siklus II, pelaksanaan penelitian pada umumnya sudah berjalan seperti yang diharapkan, ini kemungkinan besar karena siswa sudah terbiasa melakukan percobaan 
dan berdiskusi dengan metode yang diterapkan.Berdasarkan hasil pengamatan observer dan kolaborasi setelah proses pembelajaran diperoleh hal-hal sebagai berikut: (1) memotivasi dan mengaktifkan siswa dengan metode eksperimen terlihat ada kemajuan aktivitas, siswa semakin serius dalam belajar. (2) penguasaan konsep juga ada kemajuan kearah yang lebih baik. Dengan adanya kerja kelompok siswa saling kerja sama, tentang sumber bunyi yang dihasilkan oleh benda yang bergetar. Sebelum melaporkan hasil, siswa memeriksa kebenarannya dalam kelompok masingmasing.Disinilah interaksi antara siswa sangat tampak, apabila interaksi mengalami hambatan guru membvimbing dan mengarahkan pekerjaan siswa. (3) pengelolaan waktu sudah berlangsung baik dibandingkan siklus I. Setelah pertemuan ini selesai, diadakan penilaian untuk melihat hasil belajar siswa pada siklus II.

Dari 30 orang siswa yang mengikuti penilaian yang diadakan diakhir siklus II terdapat 30 orang yang mendapatkan nilai 70 keatas sesuai dengan standar keberhasilan yang ditetapkan yaitu 70, sehinggan siswa tersebut dikatakan tuntas dalam belajar, Hasil belajar dapat dilihat pada lampiran 22.Dari hasil yang didapat pada siklus kedua ini, perencanaan, pelaksanaan, dan hasil belajar sudah semakin menunjukan peningkatan.Mengenai hasil belajar siswa terlihat banyak peningkatan, buktinya pada siklus II ini siswa sudah tuntas semua.

\section{Kesimpulan}

Berdasarkan hasil analisis dan pembahasan pada bab IV di atas dapat disimpulkan bahwa Dari hasil penelitian yang telah dilakukan, dapat diambil beberapa kesimpulan yaitu: pembelajaran dengan menggunakan Metode Eksperimen dapat membuat pembelajaran lebih bermakna dan membuat siswa percaya dengan yang dipelajari, serta siswa lebih aktif pada saat belajar dan tujuan pembelajaran pun dapat tercapai dengan baik, selain itu siswa menunjukan respon yang positif. Hal ini dapat dilihat dari semangat dan kemauan siswa pada saat melakukan percobaan.Perencanaan atau RPP yang matang oleh guru terutama memilih dan penggunaan metode, serta pembagian kelompok siswa dapat memotivasi siswa untuk belajar melakukan kerja sama yang baik dalam kelompok. Disamping itu pentingnya bimbingan dan pengawasan guru dari kelompok kekelompok saat siswa melakukan eksperimen.Pelaksanaan RPP yang telah dirancang dengan baik sesuai langkahlangkah metode eksperimen dapat memotivasi siswa dalam belajar IPA.Hasil pembelajaran siswa yang didapat baik itu dari penilaian proses dan penilaian hasil ternyata juga lebih baik. Penggunaan metode eksperimen dalam pembelajaran IPA dapat meningkatkan hasil belajar IPA.Peningkatan hasil belajar dapat dilihat dari hasil belajar.

\section{DAFTAR PUSTAKA}

Abitur A. 2004. Sains Untuk Sekolah Dasar (SD) Kelas IV.Jakarta: Tropica.

Depdiknas. 2006. Kurikulum Tingkat Satuan Pendidikan (KTSP). Jakarta: Depdiknas.

Haryanto. 2004. Sains Untuk Sekolah Dasar Kelas IV. Jakarta: Erlangga.

Hamalik, Oemar. 2007. Kurikulum dan Pembelajaran. Jakarta: Bumi Aksara.

R. Ibrahim, dkk. 2007. Perencanaan Pengajaran. Jakarta: Rineka Cipta.

Rita Wati M, dkk. 2007. Metodologi Penelitian Tindakan Kelas. UNP: Padang.

Udin S. Winaputra, dkk. 1992. Strategi Belajar Mengajar IPA. Jakarta: Universitas Terbuka, Depdikbud.

Usman Samatowa. 2006. Bagaimana Membelajarkan IPA di Sekolah Dasar. Jakarta: Depdiknas.

Anonim.2017http://.google.co.id/search=peng uasaan iptek.diakses tanggal 27-032017. 10.30 Wib.

Anonim. 2017. http://. www.UNY.ac.id/ akademik/sharefile/files/1009 2007234451/.hakikat IPA.doc.diakses tanggal 27-03-2017. 10.30 Wib. 